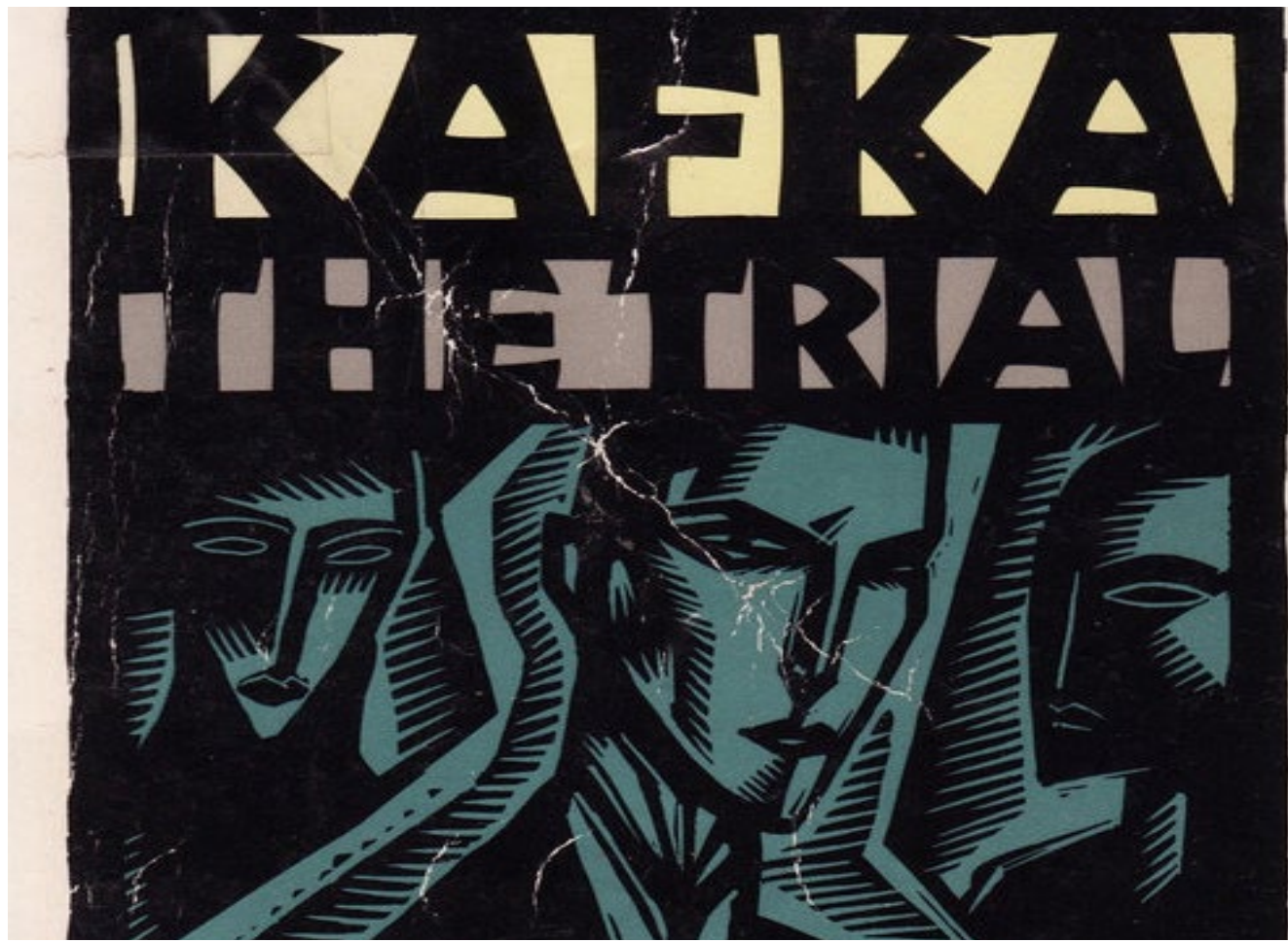

Franz Kafka's The Trial. Photo: Are.na.

\title{
Confessions Made in China
}

Magnus FISKESJÖ

Over the last few years, the Chinese authorities have repeatedly coerced political prisoners to go on television and debase themselves in forced confessions of their 'crimes'. These gruesome spectacles have featured lawyers, journalists, publishers, bloggers, music stars, and many others with an independent voice. In this essay, Magnus Fiskesjö addresses how mass media outside of the control of Chinese state authorities should deal with these grim performances. 
media outside of the control of Chinese state authorities do with these grim performances? Some have handled this problem with integrity, others disgracefully.

Over the last few years, there has been a long string of these coerced confessions, in which the Chinese authorities force political prisoners to go on television and debase themselves. These gruesome spectacles have featured lawyers, journalists, publishers, bloggers, music stars, and many others with an independent voice. To the dismay of their friends, colleagues, and relatives, after disappearing into the hands of the authorities, these victims will appear on the screen to denounce themselves and everything they used to stand for. Inside China many, if not most, people know that it is all fake and meant to intimidate and browbeat people into silence. Chinese citizens know that they cannot denounce this game openly, or they could end up on the stand themselves. In this regard, the tactic is largely effective.

\section{Between Stalin and Kafka}

These fake confessions represent a modernised version of Stalin's show-trials. They violate both international and Chinese law, and several prominent Chinese judges and legal officials have protested bravely, arguing that legal matters are supposed to be decided in the courts, not on television (Fiskesjö 2017). The spectacles fly in the face of the painstaking effort to build up the 'rule of law' in China over the decades since Mao's death. But today, we no longer hear the admonitions, previously issued by Chinese judicial authorities, to stop police torture and forced confessions (Xinhua 2012). In the increasingly harsh environment inside China, it has become too dangerous to openly criticise these spectacles.

In one of the latest cases, in February 2018 Swedish publisher Gui Minhai-who is an old friend, and who has been detained in China since he was kidnapped from Thailand by
Chinese agents in late 2015-was put up for his third mock 'interview' attended by select, pliant Chinese media (Phillips 2018). The previous two occasions involved his selfsmearing (along the lines of Josef K. in Kafka's The Trial), first with regard to an old criminal offence dug up for the purpose, and secondly with regard to the main issue, his publishing and book-selling in Hong Kong.

This third time, the spectacle's producers included not just the usual propaganda arms of the regime (e.g. the Xinhua News Agency, etc.), but also the formerly independent South China Morning Post (SCMP) of Hong Kong. In agreeing to 'interview' a torture victim in between the torture sessions, the paper gave in to pressure from China, exerted by its new Chinese owners (Alibaba). Recently, the paper has given many signs of taking directions from its new masters, and this scandalous decision came on the heels of another similarly planted interview made under duress, with the imprisoned legal assistant Zhao Wei (Phillips 2016). It certainly shows the SCMP can no longer be trusted as an independent news organisation.

\section{Behind the Headlines}

But the question for free media organisations remains: how to report the ghastly spectacles? Some have tried to stick to the old journalistic principle of reporting 'both sides', however misplaced this may be with the flagrant gross inequality in the situation of prisoners who are speaking under duress. These media, instead of pointing out the deceit themselves, often cite human rights organisations stating that these are fake events. Readers are then expected to be their own judge. But many people outside of the Chinese context are not used to imagining that an 'interview' could be faked and orchestrated through torture. The news media owe it to their readers to make clear, that this is what is now happening. 


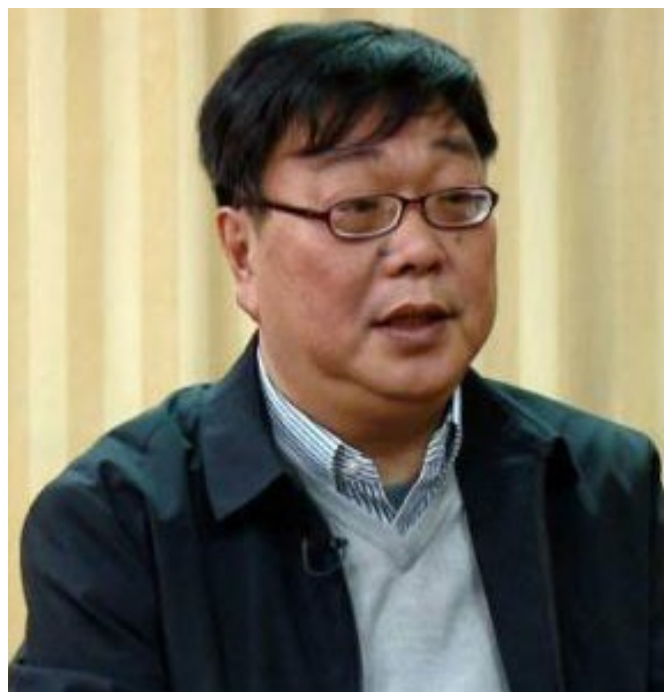

Gui Minhai.

Photo: People.cn.

Headlines become very important here, since they frame the issue for most readers. It is a perennial issue for newspapers that headline-writing page editors fail to grasp what their journalists reported. Thus, perhaps out of ignorance, we sometimes see headlines on otherwise acceptable articles, which misleadingly say that the victims 'speak' as if they were in a position to freely express themselves. This is bound to mislead readersmany of whom only read the headlines.

One example was the report from NHK World on the day after the 'interview', headlined 'Hong Kong bookseller criticises Sweden' (NHK World 2018). This headline is gravely misleading, as it omits the fact that the bookseller in question, Swedish citizen Gui Minhai, was not voluntarily 'criticising', but forced to criticise his adopted country according to a script. In his situation, he is well aware of the fact that following the script is the only way to hope to avoid more torture, harm coming to his relatives, or even death. For news media like the NHK to omit this is truly

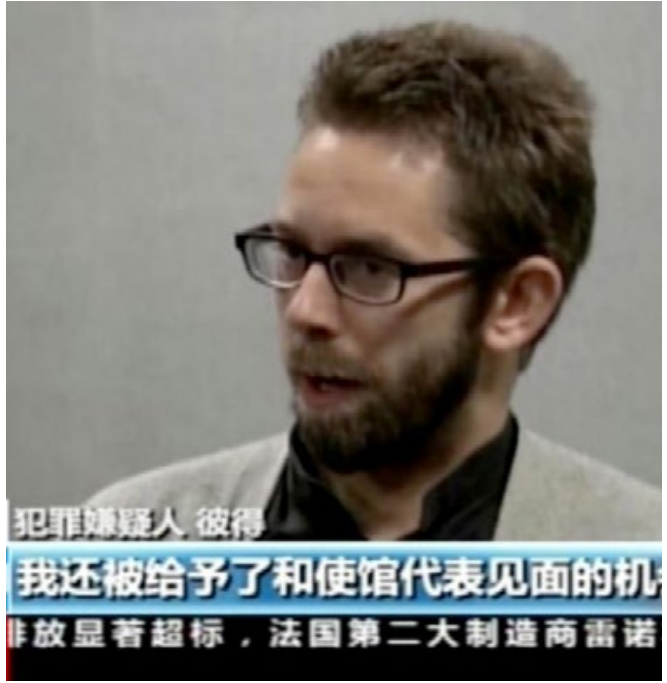

Peter Dahlin pictured

during his forced

confession on CCTV.

Photo: CCTV13.

atrocious. They offer no more than a buried hint, that the victim 'met with reporters ... while under supervision at a detention facility.'

Another striking and shameful example came in Norway's leading daily paper, the Aftenposten, also on 10 February 2018 (Rønneberg 2018). The headline proclaims, as a matter of fact, that 'Gui thinks' Sweden is using him as a 'chess piece'. This is, of course, the Aftenposten itself becoming the chess piece of the Chinese torturers. News reports like this one will mislead many readers into thinking the victim spoke his own mind, and these media all become complicit in the Chinese authorities' scheme. These are successfully planted propaganda victories.

Early on in the saga, while the Chinese authorities were focussed on destroying his bookstore in Hong Kong, Gui Minhai was quite successfully discredited by means of digging up and twisting of an old traffic incident that in fact appears to have been resolved long ago and in accordance with the laws of that time (Bandurski 2016; Huang 2017). Yet many media organisations and even the government 
in my country, Sweden, fell for this scheme by continually referring to it as a reason for Gui's detainment.

One low point was when, in a television segment that featured Gui's abduction and illegal imprisonment, a national public television journalist spent a great deal of his allotted time on stage pressing the nonquestion, 'What about the traffic incident?'probably under the false impression that he was pursuing 'both sides' in the name of 'fairness'. It was a scary display of how authoritarian China managed to stage direct Swedish journalists, without even setting foot in the newsroom. Such victories have allowed the Chinese authorities to focus on their main goals: to close and dismantle Gui's bookstore, while intimidating the entire Hong Kong publishing industry, thus sending a message to the rest of Hong Kong and the world.

\section{Upholding the Truth}

Most Swedish media have by now largely woken up to what China is doing, although occasionally there are still ignorant editors who are naïvely continuing to make similar mistakes, unwittingly serving as the conduits of this most insidious form of state propaganda that uses live people as props. The coerced character of these spectacles should be obvious to any independent observer, including how they commonly make use of personal flaws in the prisoners' past, so as to smear and discredit those targeted. This allows the Chinese authorities to achieve their main goal: to silence these voices. Free media owe it to their readers to explain that these performances offer insights only into the torturers' scheme, and not into the victim's real views; they should not leave out the fact that no alternative views or protests are tolerated in China.

We actually already know a lot about the concrete procedures behind these fake confessions, and in substantial detail. Multiple victims, when regaining a chance to speak freely, have given us accounts of how it works. Recent major examples include Gui Minhai's heroic colleague Lam Wing-kee and the brave female lawyer Wang Yu-both of whom spoke out despite the immense risk of repercussions (France 24 2018; HKFP 2016). Several foreigners detained and treated according to the same program have also given us similar accounts, including another Swedish citizen, Peter Dahlin (China Change 2017). The victim is intimidated through a series of measures that can be called modern 'clean' or 'stealth' torture (Rejali 2009): sleep deprivation, extended isolation, being forced to stand for long periods, excessive heat or cold, threats against family members and colleagues on the outside, etc. These measures will break down almost anyone. In the end, very few of us, if any, would refuse to read the script for the cameras.

But if we want to avoid being intimidated or becoming complicit, we must refuse to be duped. We must expose and protest against the charade and demand the release of those who, like Gui Minhai, have been violated in this way. And we must ask our media to take it as their duty to spell out the horrible truth: the forced confessions are scripted performances directed by the jailers, from behind a fake stage. We should also clearly distinguish these horrors from the kind of police misconduct, corruption, and torture seen in many, if not all, countries around the world. This is different, because we are not talking about rogue policemen, or even horrifying conspiratorial police torture rings, like the one exposed by the Chicago Tribune (Berlatsky 2014).

We are talking about a political crime wave, orchestrated by a government-run propaganda machine that uses living human beings as props and tools for political influence. To be sure, there are other comparable examples, such as the Islamic State in its infamous victim videos shot just before their execution. But China's campaign is especially dangerous because of the country's increasing weight in the world, which it is now throwing around in order to redefine the 'truth' by force. We should not let them. 
This text is taken from Dog Days: A Year of Chinese Labour, Civil Society, and Rights, Made in China Yearbook 2018, edited by Ivan Franceschini and Nicholas Loubere, published 2019 by ANU Press, The Australian National University, Canberra, Australia.

doi.org/10.22459/MIC.04.2019.27 